\title{
Seaweed Extract, Humic Acid, and Propiconazole Improve Tall Fescue Sod Heat Tolerance and Posttransplant Quality
}

\author{
Xunzhong Zhang1, E.H. Ervin, and R.E. Schmidt \\ Department of Crop and Soil Environmental Sciences, Virginia Tech, \\ Blacksburg, VA 24061-0404
}

Additional index words. chlorophyll fluorescence, photochemical efficiency, root strength, injury, plant metabolic enhancer, sod shelf life

\begin{abstract}
Decline of sod quality during the transportation, storage, and transplant stages of sale is a primary economic concern of sod producers. However, the mechanisms of extending sod quality during storage, transportation, and transplantation remain unclear. This study was conducted to investigate the influences of selected plant metabolic enhancers (PMEs) seaweed (Ascophyllum nodosum Jol.) extract (SWE), humic acid [93\% a.i. (HA)], and propiconazole (PPC), on sod tolerance to stress during storage and posttransplant root growth of tall fescue (Festuca arundinacea Schreb.) sod. The SWE + HA, and PPC were applied alone, or in a combination, to tall fescue 2 weeks before harvest. Photochemical efficiency (PE) of photosystem II was measured immediately before harvest. The harvested sod was subjected to high temperature stress $\left(40^{\circ} \mathrm{C}\right)$ for 72 or 96 hours. The heated sod was replanted in the field and posttransplant injury and root strength were determined. On average over 1999 and 2000 , application of SWE $\left(50 \mathrm{mg} \cdot \mathrm{m}^{-2}\right)+\mathrm{HA}\left(150 \mathrm{mg} \cdot \mathrm{m}^{-2}\right)$, PPC $\left(0.30 \mathrm{~mL} \cdot \mathrm{m}^{-2}\right)$, and a combination of $\mathrm{SWE}+\mathrm{HA}$ with PPC $\left(0.15 \mathrm{~mL} \cdot \mathrm{m}^{-2}\right)$, enhanced PE of preharvest sod by $8.5 \%, 9.1 \%$, and $11.2 \%$, respectively, and increased posttransplant rooting by $20.6 \%, 34.6 \%$, and $20.2 \%$, respectively. All PME treatments reduced visual injury except SWE + HA and SWE + HA + PPC in 1999. Extension of heat duration from 72 to 96 hours caused significantly more injury to the sod and reduced posttransplant rooting by $22.9 \%$ averaged over 2 years. The data suggest that foliar application of SWE + HA, PPC alone, or in a combination with SWE + HA, may reduce shipment heat injury and improve posttransplant rooting and quality of tall fescue sod. Chemical name used: 1-(2-(2,4-dichloropheny)-4-propyl-1,3-dioxolan-2yl)methyl-1- $\mathrm{H}$-1,2,4-triazole [propiconazole (PPC)].
\end{abstract}

Tall fescue (Festuca arundinacea Schreb.) is a widely used cool season turfgrass species occasionally used for sod production in the United States. However, sod frequently experiences severe environmental stress, especially supraoptimal temperatures, during the transportation, storage, and transplanting stages of sale (King et al., 1982). Sod often loses its color several days after transplanting, expressing a condition called transplant shock (Giese et al., 1997; Heckman, et al., 2001).

Abiotic stresses may damage plants through accumulation of free radicals in cells (Zhang, 1997; Zhang and Schmidt, 1997). After harvest and during transport, sod is exposed to an adverse environment characterized by high temperature and lack of light. Carbohydrate reserves are likely depleted rapidly due to elevated respiration rates and a lack of photosynthesis. Watschke et al. (1970) noted that carbohydrate reserves were reduced by $12.7 \%$ to $9.8 \%$ of dry weight when Kentucky bluegrass was shifted from $10 / 10^{\circ} \mathrm{C}$ to $35 / 20$

Received for publication 14 Jan. 2002. Accepted for publication 26 June 2002.

${ }^{1}$ To whom reprint requests should be addressed. Fax: (540) 231-3431; tel: (540) 231-3684; e-mail address: xuzhang@vt.edu
${ }^{\circ} \mathrm{C}$ (day/night) temperature conditions. King et al. (1982) noted that high temperatures during simulated shipping were more consistently injurious to Merion Kentucky bluegrass sod than other factors tested. When heat-stressed sod is transplanted into a field with high radiation, including ultraviolet (UV) wavelengths, greater damage may occur possibly through UV-induced photo-oxidation (Smirnoff, 1995; Schmidt and Zhang, 2001).

Rapid root growth of sod after transplanting is important for survival and successful establishment (Giese et al., 1997; Goatley and Schmidt, 1991). Natural and synthetic plant metabolic enhancers (PMEs) have been used to enhance turfgrass growth and tolerance to environmental stresses, including UV radiation and high temperature (Ervin et al., 2001; Schmidt and Zhang, 2001). Heckman et al. (2001) reported that trinexapac-ethyl reduced the internal temperature of Kentucky bluegrass sod stacks after $48 \mathrm{~h}$ of storage. Application of benzyladenine and PPC have been shown to increase tensile strength of Kentucky bluegrass sod by as much as $23 \%$ (Goatley and Schmidt, 1991). Some PMEs, such as SWE, HA, and PPC, may enhance root growth of grass subjected to stress, possibly by improving stress tolerance via enhancement of the antioxidant defense system (Allen et al., 2001; Schmidt and Zhang, 1997; Zhang and Schmidt, 1999, 2000a, 2000b).

Seaweed extract contains phytohormones, vitamins, amino acids, and mineral nutrients (Fike et al., 2001; Yan, 1993). However, its influence, particularly for stimulating turfgrasses growing under environmental stresses, may be due to its hormonal activity (Sanderson and Jameson, 1986). Humic acid is one of the three fractions (humic acid, fulvic acid, and humins) of humic substances that is insoluble below $\mathrm{pH}$ 2.0. Humic acid, when applied to plants such as peas (Pisum sativum L.), exhibited auxin-like activity in stimulating root growth (Cacco and Dell Agnola, 1984; Clapp et al., 1998; O’Donnell, 1973; Young and Chen, 1997). Propiconazole, a synthetic fungicide, has been shown to have plant growth regulating properties (Fletcher et al., 1986; Yan, 1993). These materials have been shown to enhance PE and root and shoot growth of Kentucky bluegrass and creeping bentgrass (Goatley and Schmidt, 1990, 1991; Zhang and Schmidt, 2000a). However, there are few studies concerning the influence of these PMEs on PE and postharvest sod survival. The objectives of this study were to investigate the influence of selected PMEs on posttransplant recovery and root strength of tall fescue sod following artificial heating; and to examine the relationship between preharvest $\mathrm{PE}$ and postharvest root growth of tall fescue sod subjected to postharvest stress.

\section{Materials and Methods}

Mature (3-year-old) tall fescue ('Rebel Jr.'), grown on a Groseclose silt loam soil (clayey, Kaolinitic, mesic Typic Hapludult, pH 6.2, OM $2.2 \%$ ) at the Virginia Tech Turfgrass Research Center, Blacksburg, was used for this study. The area was irrigated to prevent wilting and mowed weekly at $5 \mathrm{~cm}$. The herbicides $2,4-D(2,4-$ dichlorophenoxyacetic acid) at $0.46 \mathrm{~g} \cdot \mathrm{m}^{-2}$ plus dicamba (3,6-dichlorophenoxyacetic acid) at $0.23 \mathrm{~g} \cdot \mathrm{m}^{-2}$, pendimethalin $[N$-(1-ethylpropyl)3,4-dimethyl-2,6-dinitrobezenamine] at 0.27 $\mathrm{g} \cdot \mathrm{m}^{-2}$ were applied in late Apr. 1999 and 2000, and the insecticide Dursban [chlorpyrifos; $O, O$-diethyl $O$-(3,5,6-trichloro-2-pyridyl) phosphorothioate, a.i. $2 \%$ ] at $0.46 \mathrm{~g} \cdot \mathrm{m}^{-2}$ was applied in late June of both years. Nitrogen was applied at $0.005 \mathrm{~kg} \cdot \mathrm{m}^{-2}$ of $\mathrm{N}$ as urea in May 1999 and 2000 . Additionally, $0.005 \mathrm{~kg} \cdot \mathrm{m}^{-2}$ of $\mathrm{N}$ was supplied with a $10 \mathrm{~N}-4.6 \mathrm{P}-8.3 \mathrm{~K}$ fertilizer in Oct. 1998 and 1999.

The PME treatments consisted of the following: 1) SWE + HA (50 mg + 150 $\left.\left.\left.\mathrm{mg} \cdot \mathrm{m}^{-2}\right) ; 2\right) \mathrm{PPC}\left(0.30 \mathrm{~mL} \cdot \mathrm{m}^{-2}\right) ; 3\right) \mathrm{SWE}+\mathrm{HA}$ + PPC (50 mg + $\left.150 \mathrm{mg}+0.15 \mathrm{~mL} \cdot \mathrm{m}^{-2}\right)$; and 4) untreated control. Seaweed (Ascophyllum nodosum Jol.) extract, a dry powder, was supplied by Acadian Seaplants Ltd. (Dartmouth, Nova Scotia, Canada). Humic acid (a.i. 93\% leonardite-based) was provided by Plant Wise Biostimulants (Louisville, Ky.). Propiconazole (a.i. 14.3\%) was supplied by Syngenta Crop Protection (Greensboro, N.C.). The PMEs were applied over the foliage with a compressed-air boom sprayer delivering 
$784 \mathrm{~L} \cdot \mathrm{ha}^{-1}$ water solution of the chemicals at $290 \mathrm{kPa} 2$ weeks before harvest in both 1999 and 2000.

Plots $(1.8 \times 1.8 \mathrm{~m})$ were arranged in a randomized complete-block design with four replications. Data were subjected to analysis of variance and mean separations were performed with a protected least significant difference (LSD) test (SAS, 1988).

For the heat treatment, two pieces of sod $(0.3 \mathrm{~m} \times 1.8 \mathrm{~m})$ were removed from each plot on 2 Aug. 1999 and 25 Aug. 2000, rolled and placed in a storage building set to maintain a uniform $40{ }^{\circ} \mathrm{C}$. This building was engineered to heat sod similar to that stored during summer months in the center of pallet stacks or rolls (Heckman et al., 2001; King et al., 1982). A thermocouple was inserted into the center of each roll to ascertain temperature. The temperature inside the rolls and air temperature inside the storage building were uniformly 40 ${ }^{\circ} \mathrm{C}$ during the heat treatment period.

A sod roll from each treated plot was removed from the building after 72 and 96 $\mathrm{h}$, respectively, and transplanted $30 \mathrm{~cm}$ apart onto a prepared field [Groseclose silt loam soil (clayey, Kaolinitic, mesic Typic Hapludult, $\mathrm{pH}$ $6.2, \mathrm{OM} 2.2 \%)]$. A piece of $\operatorname{sod}(0.3 \mathrm{~m} \times 0.3 \mathrm{~m})$ was cut from the center of the roll and a $0.3 \mathrm{~m}$ $\times 0.3 \mathrm{~m}$ sheet of expanded metal was inserted under this piece of sod for subsequent root strength determination (Schmidt et al., 1986). Siduron [a.i. 50.0\%; Tupersan; 1-(2-methylcyclohexyl)-3-phenylurea] was applied at 1.2 $\mathrm{mg} \cdot \mathrm{m}^{-2}$ (a.i.) over and between the sod pieces to control weed germination. Irrigation was applied to prevent desiccation. Three weeks after transplanting, injury was rated based on a visual scale of $1-9$, with 9 indicating the most injury. Six weeks after transplanting, root strength was determined by measuring the energy required to vertically lift the expanded sheet of metal through which the sod roots had grown (Goatley and Schmidt, 1991; Schmidt et al., 1986). Briefly, the amount of force required to lift the roots free from the soil was recorded with a 100-kg handheld push/pull scale attached to the corners of the steel squares with hooks and steel cable.

Photochemical efficiency (Fv/Fm) was determined on preharvest sod by measuring chlorophyll fluorescence with a dual wavelength fluorometer (OS-50, Opti-Sciences Inc., Tyngsboro, Mass.). The ratio of variable fluorescence to maximum fluorescence at 690 $\mathrm{nm}(\mathrm{Fv} 690 \mathrm{~nm} / \mathrm{Fm} 690 \mathrm{~nm}$ or Fv/Fm) is an indicator of the photochemical efficiency of PSII or relative photochemical activity (BolharNordenkampf and Oquist, 1993; Miles, 1990). Chlorophyll fluorescence was measured on the whole turfgrass canopy consisting of mature and actively growing leaves. The sod canopy area in each plot was selected randomly and covered for $15 \mathrm{~min}$ by a PVC ring $(10-\mathrm{cm}$ diameter $\times 5 \mathrm{~cm}$ high) filled with Styrofoam (10 mm thick) for dark acclimation. A small opening (10-mm diameter) was made in the Styrofoam of each PVC ring and covered by a plastic plate. After the sod canopy was subjected to dark acclimation, the plastic plate was switched and the probe for the actinic light source was inserted immediately into the opening and pressed against the turf. Then the ring was rotated $90^{\circ}$ three times after each reading and another fluorescence measurement was collected. The values of $\mathrm{Fv} / \mathrm{Fm}$ were calculated based on averages of the three measurements.

\section{Results}

Canopy photochemical efficiency. All PME treatments enhanced PE significantly in 1999 and 2000 except SWE + HA treatment in 2000 (Table 1). The impacts of the PMEs on PE exhibited a similar trend in both years. On average over 1999 and 2000, application of SWE + HA, PPC at $0.30 \mathrm{~mL} \cdot \mathrm{m}^{-2}$, and a combination of SWE + HA with PPC at 0.15 $\mathrm{mL} \cdot \mathrm{m}^{-2}$ increased $\mathrm{PE}$ by $8.5 \%, 9.1 \%$, and $11.2 \%$, respectively.

Visual injury. Extending the heat treatment from 72 to $96 \mathrm{~h}$ caused more posttransplant visual injury in 1999 and 2000 (Table 2). The injury was less in 2000 than in 1999. This was most likely due to the mild environmental conditions (higher rainfall, lower irradiance) during the transplant period in 2000 relative to 1999 (Table 3).

There was no significant interaction between heat duration and PME treatment in either year. When averaged over heat durations, all PME treatments reduced posttransplant visual injury in 2000. In 1999, although all treatments reduced visual injury, only the turf treated with PPC had significantly reduced visual injury (Table 2).

Root strength. All PME treatments increased root strength in 1999 and 2000 following 72 and $96 \mathrm{~h}$ heat treatment (Table 2). Averaged over 1999 and 2000, SWE + HA, $\mathrm{PPC}$, and SWE + HA + PPC enhanced posttransplantrooting by $20.6 \%, 34.6 \%$, and $20.2 \%$, respectively. The PPC treatment consistently provided the greatest rooting strength. Extension of heat duration from 72 to $96 \mathrm{~h}$ reduced posttransplant rooting by $22.9 \%$ on average over 2 years. As with the visual injury data, a significant PME $\times$ heat duration interaction was not observed in either year.

\section{Discussion}

Foliar application of SWE + HA, PPC at $0.30 \mathrm{~mL} \cdot \mathrm{m}^{-2}$, or a combination of SWE + HA with $0.15 \mathrm{~mL} \cdot \mathrm{m}^{-2} \mathrm{PPC}$, significantly improved the PE of field grown tall fescue sod. This is consistent with the results of Zhang (1997) and Zhang and Schmidt (2000a) who reported that foliar application of SWE or PPC improved PE of tall fescue and creeping bentgrass under field conditions and under a water-stressed greenhouse environment. In this study, the values of $\mathrm{PE}$, ranging from 0.61 to 0.69 , were relatively lower in comparison to the PE of some nonstressed plants probably because the measurements were taken on a turf canopy consisting of leaves in various growth stages, rather than single leaves. Using the same technique under well-watered conditions, Zhang and Schmidt (2000a) obtained canopy PE values ranging from $0.31-0.55$ in July to $0.58-0.75$ in September. Liu and Huang (2001) reported a leaf $\mathrm{PE}$ ranging from $0.61-0.73$ in August in field grown creeping bentgrass.

We speculate that the increased rooting and PE we measured due to PME treatment in this study may involve the hormone-like activity of these PMEs or their effects on plant hormone balance. Propiconazole, like other triazoles, interferes with the isoprenoid pathway through inhibition of C-14 demethylation reactions that block sterol and gibberellin biosynthesis (Rademacher, 2000). In addition, a complex of cytokinins and indole 3 -acetic acid (IAA) have been identified and quantified in extracts of A. nodosum (Sanderson and Jameson, 1986; Sanderson et al., 1987; Tay et al., 1985). Bioassays have also indicated that $A$. nodosum extracts exhibit cytokinin-like activity (Allen et al., 2001; Sanderson and Jameson, 1986). Polyamines and IAA have also been quantified in humic acid preparations and their hormone-like activity in stimulating root growth has been shown in bioassays (Cacco and Dell Agnola, 1984; O'Donnell, 1973; Young and Chen, 1997). Yan (1993) showed that seaweed extract application significantly increased endogenous cytokinin level in perennial ryegrass (Lolium perenne L.).

A shift in the balance of plant hormones in response to stress has been frequently reported (Itai, 1999). During heat and moisture stress, cytokinins, auxin, and gibberellins fall, while ABA and ethylene levels rise, usually initiating senescence. Exogenous applications of PPC, SWE, and HAmay be causing endogenous shifts in the balance of hormones during the stress, increasing cytokinins, IAA, and gibberellin levels while decreasing $\mathrm{ABA}$ and ethylene (Rademacher, 2000; Yan, 1993). Previous work has demonstrated that a consequence of this supposed shift is an increase in antioxidants such as superoxide dismutase, $\alpha$-tocopherol, and ascorbic acid resulting in greater tolerance to various stresses (Mackay et al., 1987; Zhang and Schmidt, 1999, 2000a, 2000b).

Table 1. Photochemical efficiency (PE) of tall fescue (Festuca arundinacea Schreb.) sod before harvest as influenced by plant metabolic enhancers (PMEs). ${ }^{\mathrm{z}}$

\begin{tabular}{|c|c|c|c|}
\hline \multirow[b]{2}{*}{ PMEs } & \multirow[b]{2}{*}{ Rate $\left(\mathrm{m}^{-2}\right)$} & \multicolumn{2}{|c|}{ Photochemical efficiency (Fv/Fm) } \\
\hline & & 1999 & 2000 \\
\hline$\overline{\mathrm{SWE}+\mathrm{HA}^{\mathrm{y}}}$ & $50 \mathrm{mg}+150 \mathrm{mg}$ & $0.689 \mathrm{a}^{\mathrm{x}}$ & $0.650 \mathrm{ab}$ \\
\hline PPC & $0.30 \mathrm{~mL}$ & $0.676 \mathrm{a}$ & $0.668 \mathrm{a}$ \\
\hline $\mathrm{SWE}+\mathrm{HA}+\mathrm{PPC}$ & $50 \mathrm{mg}+150 \mathrm{mg}=0.15 \mathrm{~mL}$ & $0.685 \mathrm{a}$ & $0.684 \mathrm{a}$ \\
\hline Control & 0 & $0.615 \mathrm{~b}$ & $0.617 \mathrm{~b}$ \\
\hline
\end{tabular}


Table 2. Visual injury and root strength of tall fescue (Festuca arundinacea Schreb.) sod as influenced by plant metabolic enhancers (PMEs) following heat stress.

\begin{tabular}{|c|c|c|c|c|c|c|c|}
\hline \multirow[b]{2}{*}{ PMEs } & \multirow[b]{2}{*}{ Rate $\left(\mathrm{m}^{-2}\right)$} & \multicolumn{3}{|c|}{1999} & \multicolumn{3}{|c|}{2000} \\
\hline & & $72 \mathrm{~h}$ & $96 \mathrm{~h}$ & Mean & $72 \mathrm{~h}$ & $96 \mathrm{~h}$ & Mean \\
\hline & & \multicolumn{6}{|c|}{ Visual injury rating ${ }^{z}$} \\
\hline $\mathrm{SWE}+\mathrm{HA}^{\mathrm{y}}$ & $50 \mathrm{mg}+150 \mathrm{mg}$ & 6.3 & 7.3 & $6.8 \mathrm{a}^{\mathrm{x}}$ & 3.8 & 6.5 & $5.2 \mathrm{~b}$ \\
\hline PPC & $0.30 \mathrm{~mL}$ & 5.5 & 6.8 & $6.2 \mathrm{~b}$ & 2.8 & 5.8 & $4.3 \mathrm{c}$ \\
\hline $\mathrm{SWE}+\mathrm{HA}+\mathrm{PPC}$ & $50 \mathrm{mg}+150 \mathrm{mg}=0.15 \mathrm{~mL}$ & 6.0 & 7.3 & $6.7 \mathrm{a}$ & 3.5 & 6.5 & $4.5 \mathrm{c}$ \\
\hline Control & 0 & 6.3 & 7.5 & $6.9 \mathrm{a}$ & 4.3 & 7.0 & $5.7 \mathrm{a}$ \\
\hline Mean & & $5.9 \mathrm{~B}^{\mathrm{w}}$ & $7.2 \mathrm{~A}$ & & $3.6 \mathrm{~B}$ & $6.4 \mathrm{~A}$ & \\
\hline \multicolumn{8}{|l|}{ Source of variation } \\
\hline Heat duration (HD) & & & $*$ & & & $* *$ & \\
\hline PMEs & & & $*$ & & & $* *$ & \\
\hline \multirow[t]{2}{*}{$\mathrm{HD} \times \mathrm{PMEs}$} & & & NS & & & NS & \\
\hline & & \multicolumn{6}{|c|}{ Root strength $\left(\mathrm{kg} \cdot \mathrm{m}^{-2}\right)$} \\
\hline $\mathrm{SWE}+\mathrm{HA}$ & $50 \mathrm{mg}+150 \mathrm{mg}$ & 530 & 456 & $556 \mathrm{~b}$ & 933 & 625 & $796 \mathrm{~b}$ \\
\hline PPC & $0.30 \mathrm{~mL}$ & 658 & 580 & 619 a & 1003 & 778 & 890 a \\
\hline $\mathrm{SWE}+\mathrm{HA}+\mathrm{PPC}$ & $50 \mathrm{mg}+150 \mathrm{mg}+0.15 \mathrm{~mL}$ & 603 & 536 & $569 \mathrm{~b}$ & 819 & 733 & 779 bc \\
\hline Control & 0 & 496 & 411 & $441 \mathrm{c}$ & 750 & 611 & $680 \mathrm{c}$ \\
\hline Mean $^{w}$ & & $552 \mathrm{~A}$ & $476 \mathrm{~B}$ & & $876 \mathrm{~A}$ & $687 \mathrm{~B}$ & \\
\hline \multicolumn{8}{|l|}{ Source of variation } \\
\hline Heat duration (HD) & & & $*$ & & & $*$ & \\
\hline PMEs & & & $* *$ & & & $* *$ & \\
\hline $\mathrm{HD} \times \mathrm{PMEs}$ & & & NS & & & NS & \\
\hline
\end{tabular}

${ }^{2}$ Visual injury was rated on a scale of $1-9$, with 9 indicating the most injury.

${ }^{y} \mathrm{SWE}=$ seaweed extract; $\mathrm{HA}=$ humic acid; and $\mathrm{PPC}=$ propiconazole.

${ }^{x}$ Values within same column each year with same letter are not different significantly at $P=0.05$.

${ }^{\text {w}}$ Means within same row each year with same letter are not different significantly at $P=0.05$.

Table 3. Comparison of temperature, rainfall, and radiation between 1999 and 2000.

\begin{tabular}{|c|c|c|c|c|c|c|}
\hline \multirow[b]{2}{*}{ Year } & \multirow[b]{2}{*}{ Month } & \multicolumn{3}{|c|}{ Air temp $\left({ }^{\circ} \mathrm{C}\right)$} & \multirow{2}{*}{$\begin{array}{c}\text { Rainfall } \\
(\mathrm{mm})\end{array}$} & \multirow{2}{*}{$\begin{array}{c}\text { Global radiation } \\
\left(\mathrm{Kw} \cdot \mathrm{m}^{-2}\right)\end{array}$} \\
\hline & & Mean & Maximum & Minimum & & \\
\hline$\overline{1999}$ & Aug. & 20.4 & 31.9 & 9.0 & 66 & 186.7 \\
\hline 2000 & Aug. & 19.7 & 30.1 & 14.1 & 82 & 148.9 \\
\hline 1999 & Sept. & 16.1 & 29.5 & 2.6 & 140 & 137.6 \\
\hline 2000 & Sept. & 16.4 & 27.8 & 2.0 & 112 & 117.3 \\
\hline
\end{tabular}

PME-induced increases in antioxidant content and related PE increases prior to harvest may protect photosystem II during heat stress (Table 1). Consequently, posttransplant photo-oxidative injury exacerbated by a high UV environment is decreased (Table 2). The photosynthetic apparatus is a primary target of abiotic stress. Higher PE reflects better electron transport and more efficient ATP, NADPH synthesis, and eventually $\mathrm{CO}_{2}$ reduction (Miles, 1990). Higher PE found in the sod treated with PMEs suggests that the sod may utilize radiant energy more efficiently during summer stress and accumulate more carbohydrate reserves to then be available for posttransplant recovery and rooting (Miles, 1990; Zhang and Schmidt, 2000a).

The technique used in this study simulates the high temperature and dark environments that sod experiences during storage and transportation periods in the summer months. When heat stressed sod is exposed to a full sunlight environment, photo-oxidation most likely occurs (Demmig-Adams and Adams, 1992; Ervin etal., 2001; Smirnoff, 1995). However, application of the PMEs reduced posttransplant injury. The results of this study are consistent with the findings by Schmidt and Zhang (2001), who showed that a decline of photochemical activity or PE caused by UV irradiation of Kentucky bluegrass could be partially alleviated by application of selected PMEs. This suggests that the PME applications improved PE, resulting in better resistance to UV irradiation stress after transplantation. In summary, this research has shown that tall fescue sod heat tolerance, and consequently shelf life, may be improved by enhancing preharvest $\mathrm{PE}$ via proper application of SWE + HA, PPC, or SWE = HA = PPC 2 weeks before sod harvest.

Allen, V.G., K.R Pond, K.E. Saker, J.P. Fontenot, C.P. Bagley, R.L. Ivy, R.R. Evans, R.E. Schmidt, J.H. Fike, X. Zhang, J.Y. Ayad, C.P. Brown, M.F. Miller, J.L. Montgomery, J. Mahan, D.B. Wester, and C. Melton. 2001. Tasco: Influence of brown seaweed on antioxidants in forages and livestock. A review. J. Anim. Sci. 79(E. Suppl.): E21-E31.

Bolhar-Nordenkampf, H.R. and G. Oquist. 1993. Chlorophyll fluorescence as a tool in photosynthesis research, p. 193-206. In: D.O. Hall, J.M.O. Scurlock, H.R. Bolhar-Nordenkampf, R.C. Leegood and S.P. Long (eds.). Photosynthesis and production in a changing environment: A field and laboratory manual. Chapman \& Hall, London, U.K.

Cacco, G. and G. Dell Agnola. 1984. Plant growth regulator activity of soluble humic complex. Can. J. Soil Sci. 64:225-228.

Clapp, C.E., R. Liu, V.W. Cline, Y. Chen, and M.H.B Hayes. 1998. Humic substances for enhancing turfgrass growth, p. 227-234. In: G. Davies and E.A. Ghabbour (eds.). Humic substances: Structures, properties and uses. Royal Soc. of Chem. Publ., Cambridge, U.K.

Demmig-Adams, B. and W.W. Adams III. 1992. Photoprotection and other responses of plants to high light stress. Annu. Rev. Plant Physiol.

\section{Literature Cited}

Plant Mol. Biol. 43:599-626.

Ervin, E.H., X. Zhang, and R.E. Schmidt. 2001. Influence of salicylic acid on shelf life of turfgrass sod. 2001 Agronomy Abstr. (CD-ROM). ASA, CSSA, and SSSA, Madison, Wisc.

Fike, J.H., V.G. Allen, R.E. Schmidt, X. Zhang, J.P. Fontenot, C.P. Bagley, R.L. Ivy, R.R. Evans, R.W. Coelho, and D.B. Wester. 2001. Tasco-Forage: I. Influence of a seaweed extract on antioxidant activity in tall fescue and in ruminants. J. Anim. Sci. 79:1011-1021.

Fletcher, R.A., G. Hofstra, and J. Gao. 1986. Comparative fungitoxic and plant growth regulating properties of triazole derivatives. Plant Cell Physiol. 27:367-371.

Giese, M.S., R.E. Gaussoin, R.C. Shearman, and T.P. Riordan. 1997. Sod production characteristics of turf-type Buchlo dactyloides. Intl. Turfgrass Soc. Res. J. 8:455-465.

Goatley, J.M., Jr. and R.E. Schmidt. 1990. Antisenescence activity of chemicals applied to Kentucky bluegrass. J. Amer. Soc. Hort. Sci. 115:654-656.

Goatley, J.M., Jr. and R.E. Schmidt. 1991. Biostimulator enhancement of Kentucky bluegrass sod. HortScience 26:254-255.

Heckman, N.L., G.L.Horst, R.E. Gaussoin, and K.W. Frank. 2001. Storage and handling characteristics of trinexapac-ethyl treated Kentucky bluegrass sod. HortScience 36:1127-1130.

Itai, C. 1999. Role of phytohormones in plant responses to stress. In: H.R. Lerner (ed.). Plant responses to environmental stress, p. 287-301. Marcel Dekker, New York.

King J.W., J.B. Beard, and P.E. Rieke. 1982. Factors affecting survival of Kentucky bluegrass sod under simulated shipping conditions. J. Amer. Soc. Hort. Sci. 107:634-637.

Liu, X. and B. Huang. 2001. Seasonal changes and cultivar difference in turf quality, photosynthesis, and respiration of creeping bentgrass. HortScience 36:1131-1135.

MacKay, C.E., T. Senaratna, B.D. McKersie, and R.A. Fletcher. 1987. Ozone-induced injury to cellular membranes in Triticum aestivum L. and protection by the triazole S-3307. Plant Cell Physiol. 28:1271-1278.

Miles, D. 1990. The role of chlorophyll fluorescence 
as a bioassay for assessment of toxicity in plants, p. 297-307. In: W. Wang, J.W. Gorsuch, and W.R. Lower (eds.). Stnd. Tech. Publ. 1091, Amer. Soc. for Testing and Materials. Philadelphia.

O'Donnell. 1973. The auxin-like effects of humic preparations from leonardite. Soil Sci. 116(2): 106-112.

Rademacher, W. 2000. Growth retardants: Effects on gibberellin biosynthesis and other metabolic pathways. Annu. Rev. Plant Physiol. Plant Mol. Biol. 51:501-531.

Sanderson, K.J. and P.E. Jameson, 1986. The cytokinin in a liquid seaweed extract: Could they be the active ingredients? Acta Hort. 179: 113-116.

Sanderson, K.J., P.E. Jameson, and J.A. Zabkiewicz. 1987. Auxin in a seaweed extract: identification and quantitation of indole-3-acetic acid by gas chromatography-mass spectrometry. J. Plant Physiol. 129:363-367.

SAS Institute Inc. 1988. SAS/STAT user's guide. Release 6.03 ed. SAS Inst., Cary, N.C.

Schmidt, R.E. and X. Zhang. 1997. Influence of seaweed on growth and stress tolerance of grasses, p. 158. In: M.J. Williams (ed.). Proc.
Amer. Forage Grassland Council. Vol. 6. Ft. Worth, Texas.

Schmidt, R.E. and X. Zhang. 2001. Alleviation of photochemical activity decline of turfgrasses subjected to low soil moisture or UV radiation stress. Intl. Turfgrass Res. J. 9:340-346.

Schmidt, R.E., R.H. White, and S.W. Bingham. 1986. Technique to measure rooting of sods grown in small containers. Agron. J. 78:212-216.

Smirnoff, N. 1995. Antioxidant systems and plant response to the environment, p. 217-244. In: N. Smirnoff (ed.). Environment and plant metabolism: Flexibility and acclimation. BIOS Scientific Publ., Oxford, U.K.

Tay, S.A.B, J.K. Macleod, L.M.S. Palni, and D.S. Letham. 1985. Detection of cytokinins in a seaweed extract. Phytochemistry 24:2611-2614.

Watschke, T.L., R.E. Schmidt, and R.E. Blaser. 1970. Responses of some Kentucky bluegrasses to high temperature and nitrogen fertility. Crop Sci. 10:372-376.

Yan, J.Y. 1993. Influence of plant growth regulators on turfgrass polar lipid composition, tolerance to drought and salinity stress, and nutrient efficiency. PhD Diss. Virginia Polytechnic Inst. and State Univ., Blacksburg.

Young, C.C. and L.F. Chen. 1997. Polyamines in humic acid and their effect on radical growth of lettuce seedlings. Plant Soil 195:143-149.

Zhang, X. 1997. Influences of plant growth regulators on turfgrass growth, antioxidant status, and drought tolerance. PhD. Diss., Virginia Polytechnic Inst. and State Univ., Blacksburg.

Zhang, X. and R.E. Schmidt. 1997. The impact of growth regulators on the $\alpha$-tocopherol status in water-stressed Poa pratensis. Intl. Turfgrass Soc. Res. J. 8:1364-1371.

Zhang, X. and R.E. Schmidt. 1999. Antioxidant responses to hormone-containing product in Kentucky bluegrass subjected to drought. Crop Sci. 39:545-551.

Zhang, X. and R.E. Schmidt. 2000a. Application of trinexapac-ethyl and propiconazole enhances superoxide dismutase and photochemical activity in creeping bentgrass (Agrostis stoloniferous var. palustris). J. Amer. Soc. Hort. Sci. 125:47-51.

Zhang, X. and R.E. Schmidt. 2000b. Hormone-containing products impact on antioxidant status of tall fescue and creeping bentgrass subjected to drought. Crop Sci. 40:1344-1349. 